\title{
Effect of Biofloc on Water Quality Parameters in Rohu, Labeo rohita (Hamilton) Culture Tanks
}

\author{
P. Anand Prasad ${ }^{1 *}$, H. Shivanandamuthy ${ }^{1}$, D. Ravindra Kumar Reddy ${ }^{2}$, M. Ganapathy \\ Naik $^{1}$, Gangadhara Gowda ${ }^{1}$, K. Mansingh Naik ${ }^{1}$, O. Sudhakar ${ }^{2}$ and T.V. Ramana ${ }^{2}$ \\ ${ }^{1}$ Department of Aquaculture, College of Fisheries Mangaluru, India \\ ${ }^{2}$ Department of Aquaculture, College of Fishery Science Muthukur, India
}

*Corresponding author

\section{A B S T R A C T}

Keywords

Rohu, Labeo rohita (Hamilton) Culture Tanks

Article Info

Accepted:

17 July 2018

Available Online:

10 August 2018
The present study was undertaken to investigate the effect of biofloc-based aquaculture system on water quality suitability for the growth of rohu for a period of 120 days under laboratory conditions in triplicates. Different water quality parameters were checked at weekly interval. Sugar has been given as the source of carbon and ammonium chloride as source of ammonia. Much difference was not found in the water quality parameters except nitrate, nitrite and BOD when compared to control.

\section{Introduction}

One of the novel technologies that have the potential to generate high production from intensified aquaculture system without hampering environmental, economic and social sustainability is biofloc technology (Crab et al., 2012). Originally described as activated suspension technique and developed during the eighties, this technology is based on the maintenance of high levels of microbial floc in suspension by continuous aeration (Avnimelech et al., 1986; Serfling, 2006). Constant aeration allows aerobic decomposition of organic matters viz. feed, fertilizes, faeces etc. in an aquaculture pond stocked with fish with the consequent development of a dense population of heterotrophic microorganism (Avnimelech, 1999). Such dense and suspended heterotrophic population controls water quality, becomes a protein rich food source for fish and can act as an alternative measure for pathogen control (Hargreaves, 2006).

Theoretically, the system operates through the addition of a carbon source as a fertilizer to increases the $\mathrm{C} / \mathrm{N}$ ratio which, inturn, enhances conversion of inorganic nitrogen to microbial biomass (Avnimelech, 1999). Micro-organisms utilize carbohydrate as energy source to produce new cells and nitrogen is utilized for the synthesis of protein which is also a major component in the 
formation of new cells (Avnimelech, 1999). Thus, as a basic microbial process, utilization of carbohydrate is accompanied by the immobilization of inorganic nitrogen (Avnimelech, 1999). A high C/N ratio (10-20) is recommended for development of biofloc and efficient ammonia removal (Hargreaves, 2006). This can be achieved by adding different locally available carbon sources and/or using low nitrogen feed (Hargreaves, 2006).

The benefits of biofloc technology over conventional practices in terms of water usage efficiency and dynamic changes in water quality have been successfully demonstrated in shrimp farming ( $\mathrm{Xu}$ et al., 2016) and to some extent in finfish culture (Perez- Fuentes et al., 2016). Owing to the limited work on biofloc technology application in finfish aquaculture, more researches need to be performed to include potential species under such system. Apart from being filter feeder (Chondar, 1999) and periphyton feeder (Azim et al., 2002), rohu (Labeo rohita) is also capable of ingesting bacteria in suspension (Rahmatullah and Beveridge, 1993). These attributes can make this species suitable for cultivation in biofloc based system. However, biofloc technology application for culture of this species is yet to be fully demonstrated. Moreover, in general, limited studies have investigated the potential of biofloc technology in augmenting the welfare of cultured animals, particularly in terms of water quality and immunity.

Thus, in order to assess the viability of this novel technology for culture of rohu, the experiments were designed to elucidate the water quality dynamics in biofloc technology.

\section{Materials and Methods}

The experiment has conducted in the Instructional Freshwater Fish Farm, College of
Fishery Science, Eguvamitta, Potti Sreeramulu Nellore District, Andhra Pradesh, India. 18 tanks were used made of polyethylene with the capacity of 100 liters and covered with Netlon mesh to avoid jumping of fish. Tanks were cleaned after checking the leakages and the level of water filled in each tank was 90 liters only. In the beginning rohu (Labeo rohita) weighing on an average 3 to 6 grams each were stocked with Sarvepalli Reservoir water, filled in the polythene tanks of 100 liters capacity and aeration was supplied continuously 24 hours a day. On third day rohu fishes were stocked @ 3, 4, and 5 including control in triplicates. Ground nut oil cake and rice bran was given as feed. For the development of biofloc sugar and ammonium chloride was added in each tank @ 5 grams each and later stages the ammonium chloride dose has been increased, after $3^{\text {rd }}$ day of stocking.

After one month the water colour was changed into coffee brown colour and when it was checked in emhoff cone, it was around $2.5 \mathrm{ml}$. whenever the measuring (biofloc) reached 3.5 $\mathrm{ml}$ in the cone the water exchanged about $20 \%$. In control $30 \%$ water exchange has been done weekly thrice for two weeks till water gets plankton levels and later daily once $30 \%$ water exchange has been done. Ammonium chloride has been added as source of ammonia $5 \mathrm{mg}$ every week and when the level of ammonia was decreased the dose has been doubled.

Water quality parameters were estimated weekly once including control and monthly once in treatment ponds $20 \%$ water was exchanged every alternative day $30 \%$ water in control tanks. The parameters like $\mathrm{pH}$, Dissolved oxygen, ammonia, nitrate, nitrite, alkalinity biological oxygen demand were estimated weekly in both treatment and control tanks following the standards methods (APHA, 1998). 


\section{Results and Discussion}

Water quality parameters are very important for aquaculture. The major role played in biofloc system is aeration. Because of high stocking density in less space the fishes suffer from oxygen depletion. To avoid this problem 24 hours aeration is provided with the help of compressor and one arranged as spare. During the experimental period the fishes were observed carefully. In the beginning of the experiment water exchange has been done in the control tanks two days once and when plankton levels increased in the tanks daily in the evening water exchange has been done. In the experimental tanks whenever the Imhoff cone showed $5 \mathrm{ml}$ the water has been exchanged for $20 \%$.

$\mathrm{pH}$, Dissolved oxygen, ammonia, nitrate, nitrite, alkalinity and biological oxygen demand have been estimated weekly during the experiment (120 days).
During the study period $\mathrm{pH}$ range was in between 7.4 and 7.9 including control tanks. Although the water has become more green colour in control tanks compared with experimental tanks. There was no problem observed because of $\mathrm{pH}$ in the experimental as well as control tanks.

Dissolved oxygen ranged from 5.5 to $8.0 \mathrm{ppm}$ in the $T_{1}$, in $T_{2}$ it is 6.5 to $8.0 \mathrm{ppm}$ and in $\mathrm{T}_{3}$, 6.0 to $8.0 \mathrm{ppm}$. Ammonia ranged from 0.0 to 0.43 in $\mathrm{T}_{1}, 0.0$ to $0.5 \mathrm{~T}_{2}$ and $\mathrm{T}_{3}, 0.0$ to 0.75 $\mathrm{ppm}$. Nitrate concentration was 0.0 to 0.25 , 0.42 and 0.0 to $0.04 \mathrm{ppm}$ in $\mathrm{T}_{1}, \mathrm{~T}_{2} \& \mathrm{~T}_{3}$.

Nitrite concentration was 0.00 to $0.20,0.33$ and $0.33 \mathrm{ppm}$ in treatments $1,2,3$ tanks consequently. Alkalinity ranged from 159 to 190,147 to 189 and 158 to $188 \mathrm{ppm} \mathrm{T}_{1}, \mathrm{~T}_{2}$ and $\mathrm{T}_{3}$ tanks consequently. Biological oxygen demand ranged from 3.8 to $5.3,4.2$ to 5.3 and 5.8 to $5.6 \mathrm{ppm}$ in $\mathrm{T}_{1}, \mathrm{~T}_{2}$, and $\mathrm{T}_{3}$ tanks consequently (Fig. 1, 2 and 3).

Fig.1 Treatment 1: Graphical representation of the water quality parameters are given in the table in experimental tank 3 Rohu's per tank

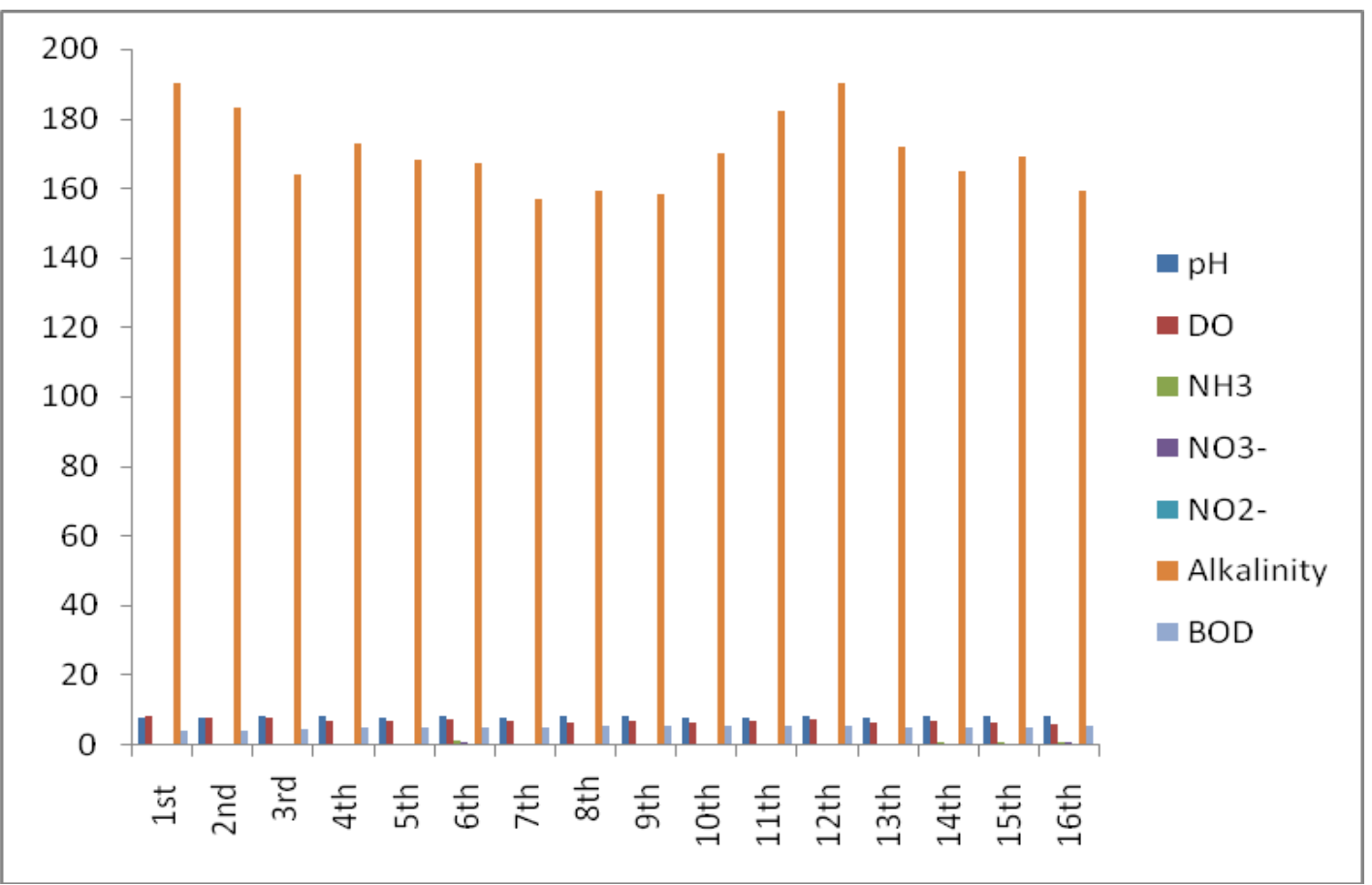


Fig.2 Treatment 2: Graphical representation of the water quality parameters are given in the table in experimental tank 4 Rohu's per tank

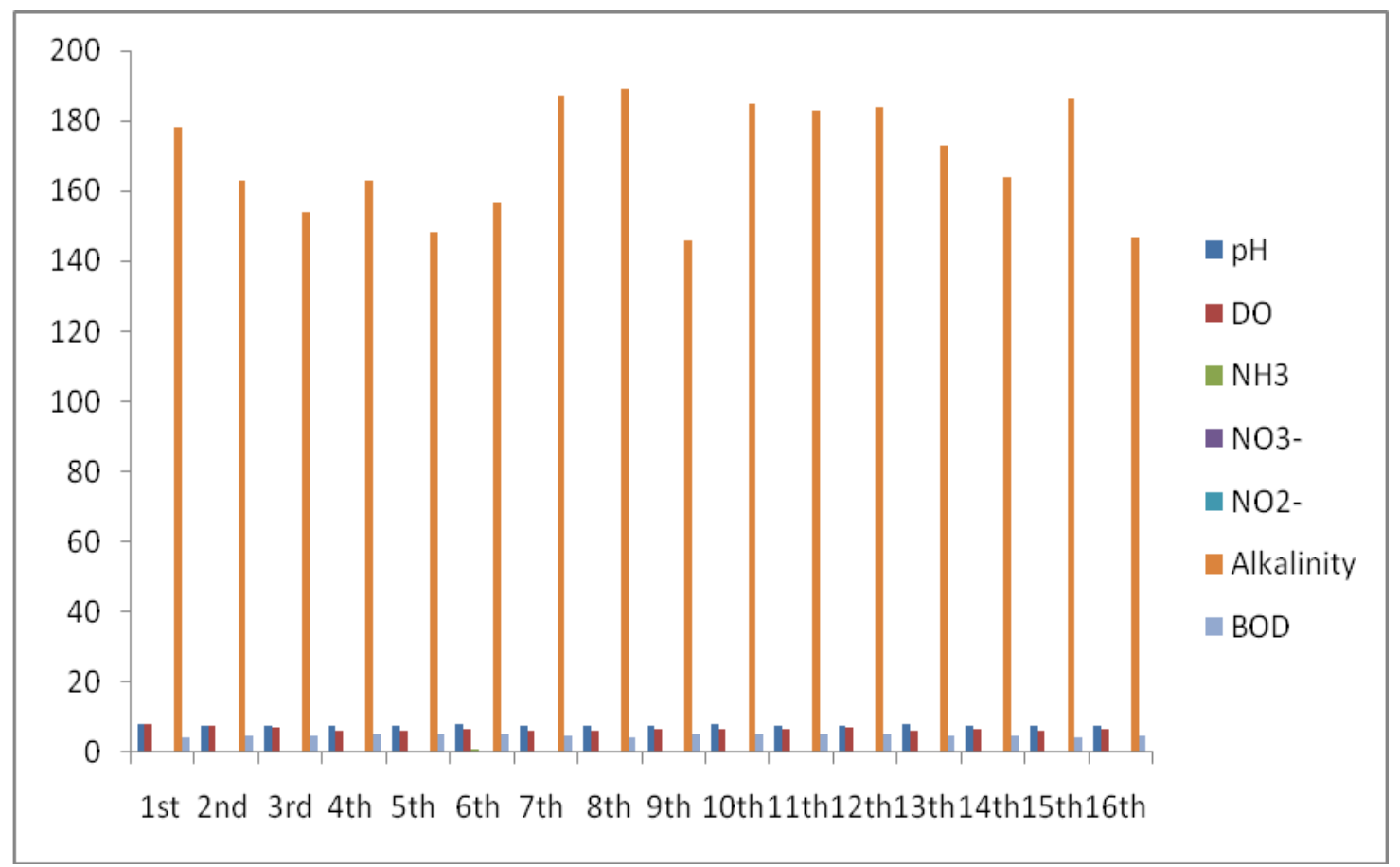

Fig.3 Treatment 3: Graphical representation of the water quality parameters are given in the table in experimental tank 5 Rohu's per tank

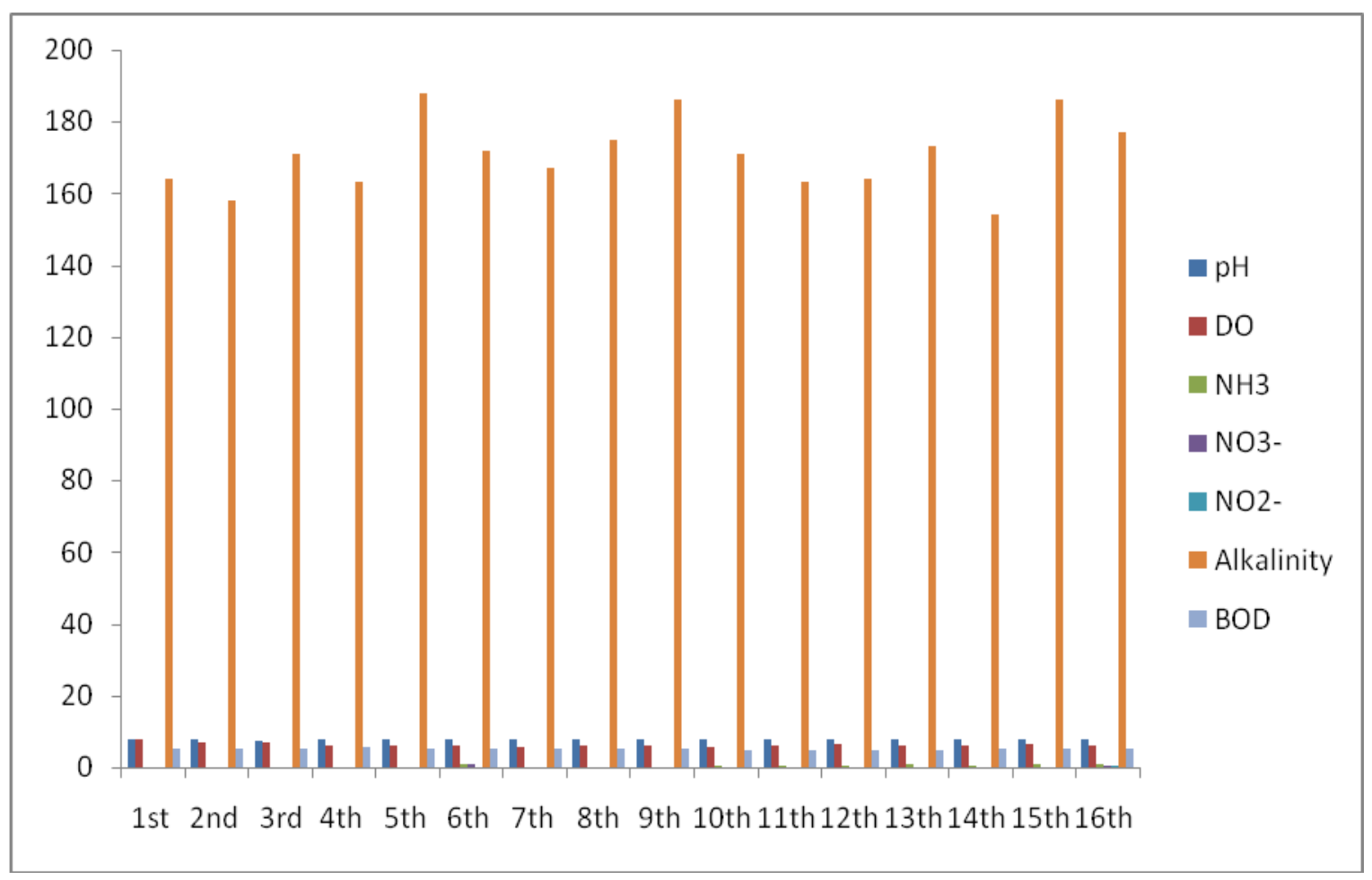


Fig.4 Control 1: Graphical representation of the water quality parameters are given in the table in experimental tank 3 Rohu's per tank

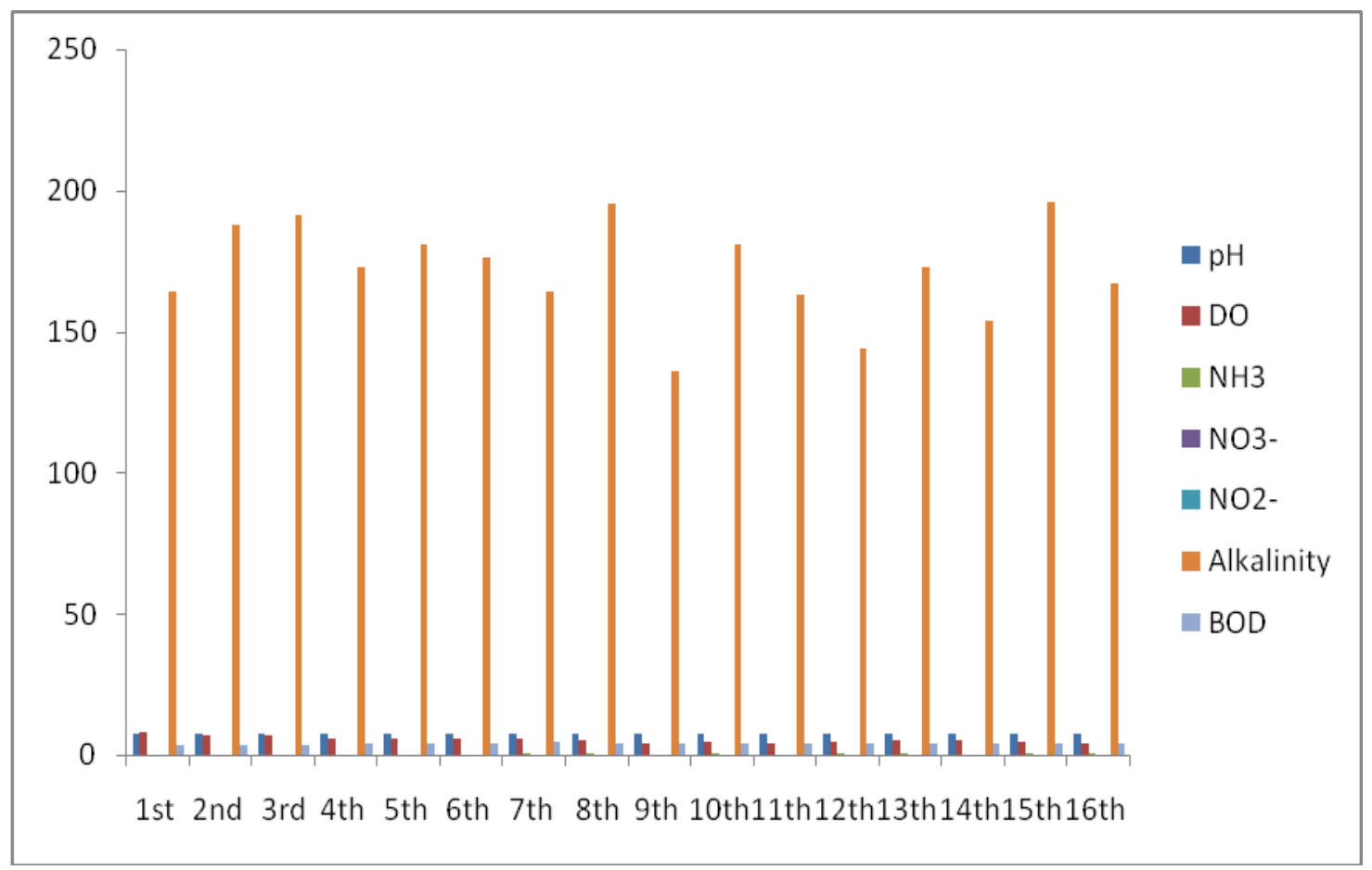

Fig.5 Control 2: Graphical representation of the water quality parameters are given in the table in experimental tank 4 Rohu's per tank

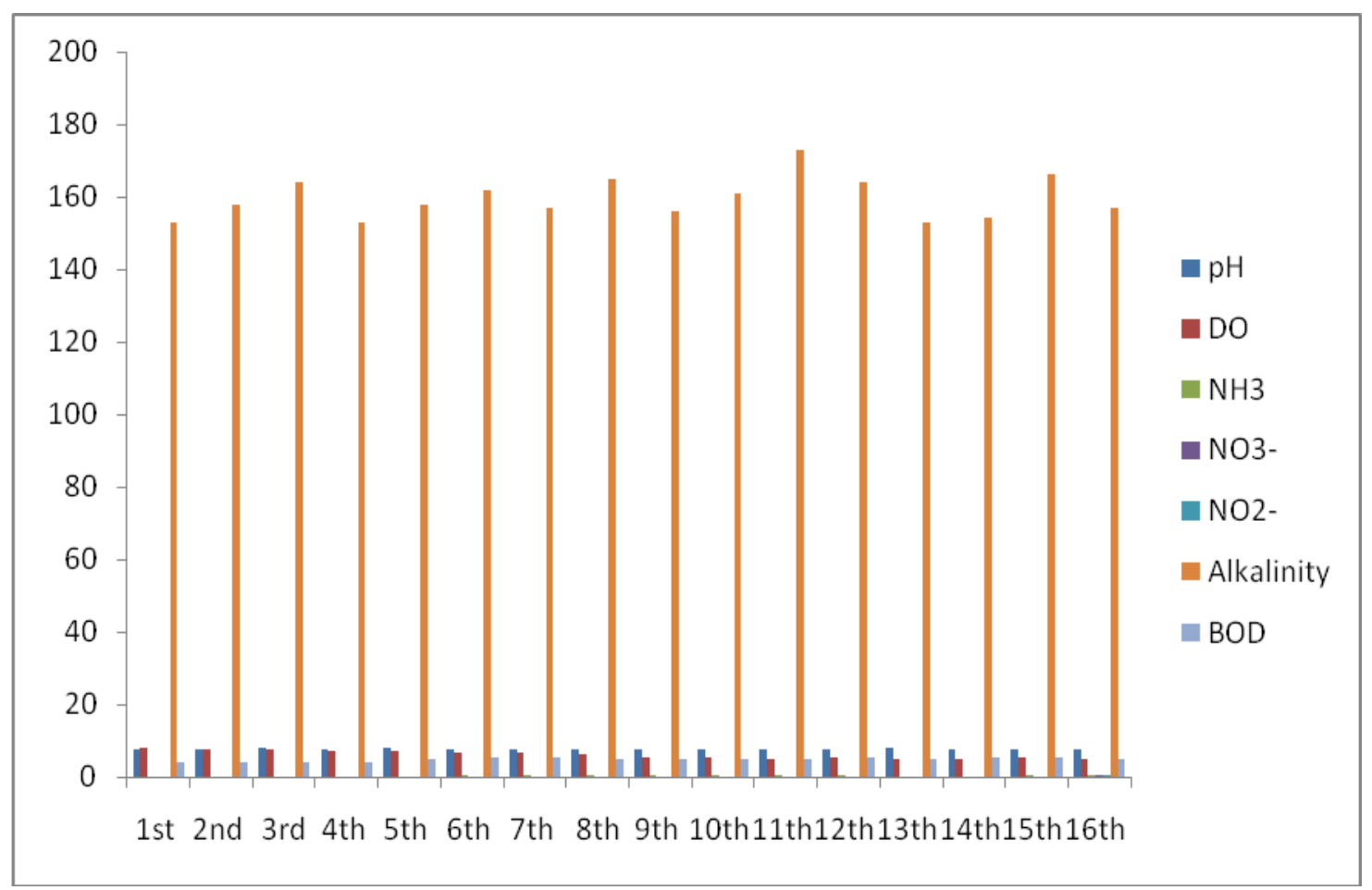


Fig.6 Control 3: Graphical representation of the water quality parameters are given in the table in experimental tank 5 Rohu's per tank

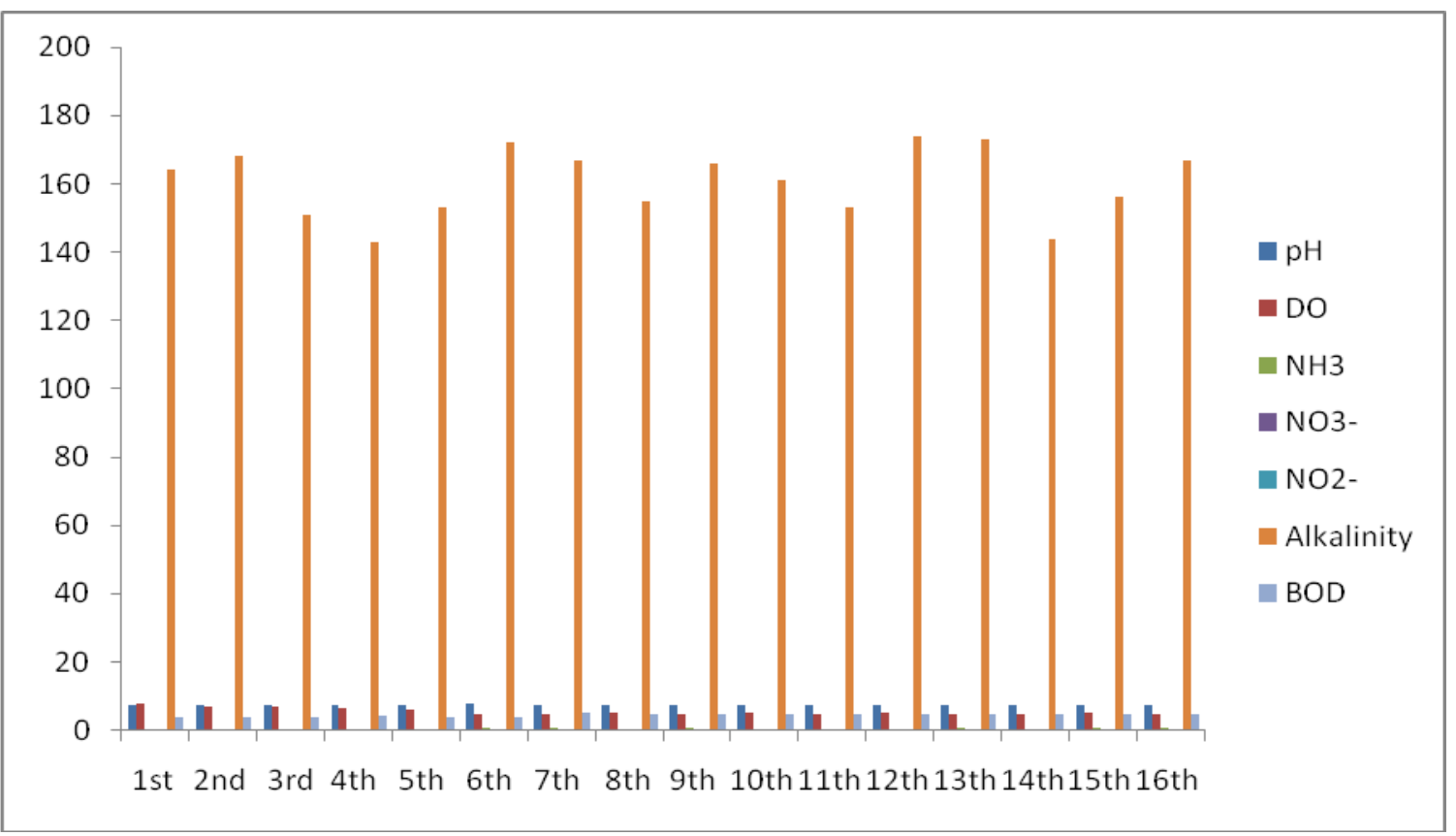

In control tanks DO ranged from 4.0 to 8.0, 5.0 to 8.0 and 5.0 to $8.0 \mathrm{ppm}$ in $\mathrm{C}_{1}, \mathrm{C}_{2}$, and $\mathrm{C}_{3}$ control tanks. Ammonia ranged from 0.0 to $0.68,0.00$ to 0.65 and 0.00 to $0.65 \mathrm{ppm}$ in $\mathrm{C}_{1}$, $\mathrm{C}_{2}$, and $\mathrm{C}_{3}$ consequently. Nitrate ranged from 0.00 to $0.40,0.00$ to 0.42 and 0.00 to 0.51 ppm in $\mathrm{C}_{1}, \mathrm{C}_{2}$, and $\mathrm{C}_{3}$ consequently. Nitrite ranged from 0.00 to $0.03,0.00$ to 0.33 and 0.00 to $0.20 \mathrm{ppm}$ in $\mathrm{C}_{1}, \mathrm{C}_{2}$, and $\mathrm{C} 3$ consequently. Alkalinity ranged from 144 to 196, 153 to 173 and 143 to 174 ppm in $\mathrm{C}_{1}, \mathrm{C}_{2}$, and $\mathrm{C}_{3}$ consequently. BOD ranged from 3.2 to 4.6, 3.8 to 5.3 and 3.9 to 5.2 ppm (Figure 4, 5 and 6).

In the present biofloc system, water quality parameters DO concentrations and $\mathrm{pH}$ were well within the acceptable limits required for tropical aquaculture (Bhatnagar and Devi, 2013). The higher oxygen utilization during nitrification coupled with nitrogen immobilization through heterotrophic pathway of microbial production which is common in biofloc system (Sharma and Ahlert, 1977).
The generation of lower levels of $\mathrm{NH}_{3}, \mathrm{NO}_{2}^{-}$ and $\mathrm{NO}_{3}{ }^{-}$may be due to the dominance of heterotrophic pathway of ammonia immobilization. In fact, biofloc system with proper $\mathrm{C} / \mathrm{N}$ ratio encourages immobilization of ammonia by heterotrophic bacteria rather than nitrification (Burford et al., 2004). Overall, the dynamics of three inorganic nitrogen species in the biofloc system indicated involvement of ammonia immobilization through heterotrophic pathway as well as nitrification.

\section{References}

APHA, 1998. Standard Methods for the Examination of the Water and Wastewater, twenty second ed. American Public Health Association, Washington, DC.

Avnimelech, Y. 1999. Carbon/nitrogen ratio as a control element in aquaculture systems. Aquaculture, 176, 227-235.

Avnimelech, Y., Weber, B., Millstien, A., Hepher, B., Zoran, M.1986. Studies in 
circulated fishponds: organic matter recycling and nitrogen transformation. Aquacult. Fish. Manage 17, 231-242.

Azim, M.E., Beveridge, M.C.M., Rahman, M.A., Wahab, M.A., Van Dam, A.A., Verdegem, M.C.J. 2002. Evaluation of polyculture of Indian major carps in periphyton-based ponds. Aquaculture. 213, 131-149.

Bhatnagar, A., Devi, P. 2013. Water quality guidelines for the management of pond fish culture. Int. J. Environ. Sci. 3, 1980-2009.

Burford, M.A., Thompson, P.J., McIntosh, R.P., Bauman, R.H., Pearson, D.C. 2004. The contribution of flocculated material to shrimp (Litopenaeus vannamei) nutrition in a high-intensity, zero-exchange system. Aquaculture. 232, 525-537.

Chondar, S.L. 1999. Biology of Finfish and Shell Fish. SCSC Publishers, Howrah, India.

Crab, R., Defoirdt, T., Bossier, P., Verstraete, W. 2012. Biofloc technology in aquaculture: beneficial effects and future challenges. Aquaculture, 351356.

Hargreaves, J.A. 2006. Photosynthetic suspended growth systems in aquaculture. Aquacult. Eng., 34, 344363.

Perez-Fuentes, J.A., Hernandez-Vergara, M.P., Perez-Rostro, C.I., Fogel, I., 2016. C: N ratios affect nitrogen removal and production of Nile tilapia Oreochromis niloticus raised in a biofloc system under high density cultivation. Aquaculture. 452, 247-251.

Rahmatullah, S.M., Beveridge, M.C.M., 1993. Ingestion of bacteria in suspension Indian major carps (Catla catla, Labeo rohita) and Chinese carps (Hypophthalmichthys molitrix, Aristichthys nobilis). Hydrobiologia. 264, 79-84

Serfling, S.A. 2006. Microbial flocs: natural treatment method supports freshwater, marine species in recirculating systems. Glob. Aquac. Advocate, 9, 34-36.

Sharma, B., Ahlert, R.C.1977. Nitrification and nitrogen removal. Water Res. 11, 897-925.

Xu, W. J., Morris, T.C., Samocha, T.M., 2016. Effects of $\mathrm{C} / \mathrm{N}$ ratio on biofloc development, water quality, and performance of Litopenaeus vannamei juveniles in a biofloc-based, high density, zero-exchange, outdoor tank system. Aquaculture. 453, 169-175.

\section{How to cite this article:}

Anand Prasad, P., H. Shivanandamuthy, D. Ravindra Kumar Reddy, M. Ganapathy Naik, Gangadhara Gowda, K. Mansingh Naik, O. Sudhakar and Ramana, T.V. 2018. Effect of Biofloc on Water Quality Parameters in Rohu, Labeo rohita (Hamilton) Culture Tanks. Int.J.Curr.Microbiol.App.Sci. 7(08): 3167-3173. doi: https://doi.org/10.20546/ijcmas.2018.708.338 